\title{
People of the Sun: The EZLN in an Age of Mass Media
}

By Blake Burgess

It is important for me, as a popular artist, to make clear to the governments of the United States and Mexico that despite the strategy of fear and intimidation to foreigners, despite their weapons, despite their immigration laws and military reserves, they will never be able to isolate the Zapatista communities from the people in the United States. ${ }^{1}$

-Zack de la Rocha, vocalist of the American rap metal band Rage Against the Machine

In an age where the transmission of ideas is instantaneous and widespread, political and ideological movements can gain momentum rapidly and receive support from a global community. The Ejército Zapatista de Liberación Nacional (EZLN) have utilized the internet and media as a tool to build support for their movement. With a somewhat mythical spokesperson, Subcomandante Marcos-who has used other noms de guerre- the EZLN have retained control over Chiapas, Mexico with little bloodshed or violence. In this paper I will provide an overview of the EZLN and its goals from its rise in 1994 to the present, examine the enigmatic Subcomandante Marcos and his role in the movement, the group's use of the internet and media as a political tool, and some perceptions on the EZLN's successes and shortcomings. The EZLN's use of the Internet and popular media, the role of Subcomandante Marcos, and establishment of autonomous communities were key to their subversion of the Mexican government and their ability to maintain a presence. While the EZLN may have not succeeded in their lofty goals of spreading their brand of autonomy and resistance to the rest of Mexico, they succeeded in their goals of local autonomy.

1 “Interview with Zach, from Chiapas, Mexico," Music Fan Clubs, July 7, 1998, accessed April 18, 2015, http://www.musicfanclubs.org/rage/articles/chiapas.htm 


\section{Origins and Evolution}

On New Year's Eve, 1993 EZLN troops made their way to San Cristobal de las Casas and Ocosingo, thus starting what Ana Carrigan calls the "first post-modern revolution;" ican government in the Chiapas region. ${ }^{3}$ These rebels were primarily indigenous Maya people and the uprising coincided with the adoption of the North American Free Trade Agreement (NAFTA). ${ }^{4}$ NAFTA removed trade barriers between Canada, the US, and Mexico. This led to impoverished rural farmers in Mexico facing competition from US farmers, which were able to more efficiently raise crops such as corn. ${ }^{5}$ The initial fighting between the EZLN and Mexican National Army only lasted twelve days and the spokesman for the EZLN, Subcomandante Marcos, used the national press to create a "dialogue with the Mexican people." 6

In an interview, Marcos explained in the mid-1980s a small group went to the jungles of Chiapas with ideological roots in political-military guerrilla organizations that were present in 1960s and 1970s Latin America. The group struggled to adapt to the guerrilla lifestyle, but held out with the hopes of eventually having some sort of result. He explained that the group not only taught the indigenous people the basics found in mestizo culture (Mexican history, reading, writing, mathematics, biology, etc.), but that the group also learned from the indigenous. The EZLN began to understand the indigenous worldview and learned to survive as the indigenous had. He noted many struggles — those of peasants, workers, and students—all inevitably clash with power, be it the State or a dominant class. And to bring about change, armed struggle seemed to be the necessary route. Marcos mentioned the EZLN broke with the Left by proposing armed revolution at the time, but it was

\footnotetext{
2 Ana Carrigan, "Chiapas: The First Post-Modern Revolution," The Fletcher Forum 19, no. 1 (1995): 71.

3 Michael Radu, "Mexico: Slouching Toward Normality," The Washington Quarterly 23, no. 3 (Summer 2000): 47.

4 Oliver Froehling, “The Cyberspace 'War of Ink and Internet' in Chiapas, Mexico," Geographical Review 87, no. 2 (April 1997): 291.

5 Courtney Jung, "The Politics of Indigenous Identity: Neoliberalism, Cultural Rights, and the Mexican Zapatistas," Social Research 70, no. 2 (2003): 439-40.

6 Ana Carrigan, "Chiapas," 71.
} 
necessary for the indigenous peoples as a defense against the ranchers who were encroaching on the indigenous communities. The dense jungle allowed for the EZLN to grow and to develop a relationship with the local people. Ultimately, Marcos explained, the line between "combatant force and civilian force" disappeared and whole communities were under the Zapatista banner. ${ }^{7}$

Over the years, the EZLN have released numerous communiqués, with the "First Declaration of the Lacandon Jungle" released simultaneously with their January 1 assault. In this the EZLN addressed the people-and the government-of Mexico, citing 500 years of struggle against foreign powers and domestic dictators (such as Porfirio Diaz) neglecting to take care of the people. According to the EZLN, it was time to modify the government, per Article 39 of Mexico's Constitution which states that national sovereignty resides in the people and that the people "have the inalienable right to alter or modify their form of government." The EZLN declared war against Carlos Salinas de Gortari's regime, which maintained a political monopoly in Mexico due to the one-party system in place. The Zapatistas also set standards for themselves and requested the Red Cross to "watch over and regulate...battles" in order to legitimize their cause. ${ }^{9}$ Furthermore, the EZLN also declared that they would follow the Geneva Accords. ${ }^{10}$ By proclaiming constitutional legitimacy and claiming to have the Mexican people on their side, and abiding by international standards and calling for international oversight, the EZLN was setting itself up as a force to be reckoned with.

The EZLN called for better "work, land, housing, education,..., democracy, justice, and peace." ${ }^{11}$ Chiapas stands in stark contrast with much of Mexico as a whole. Sixty percent of the population in Chiapas lives in rural areas; in

7 "Early and Extensive Interview with Subcomandante Marcos," Schools for Chiapas, May 1994, accessed May 17, 2015,

http://schoolsforchiapas.org/wp-content/uploads/2014/03/Interview-with-Subcomandante-Marcos.pdf. 8 General Command of the EZLN, "First Declaration of the Lacandon Jungle: EZLN's Declaration of War,” The Struggle Site, June 1993, accessed April 20, 2015, http://struggle.ws/mexico/ezln/ezlnwa.html. 9 Ibid.

10 Ibid.

11 General Command 
comparison, only about half of that number inhabits rural areas in Mexico. Nearly thirty-one percent of Chiapas was illiterate, whereas only thirteen percent of Mexico as a whole was illiterate. Access to water, electricity, and other valuable resources was more limited in Chiapas (especially in some specific cities that the EZLN had taken control of) than in the rest of Mexico; however, Chiapas was a relatively resource-rich area with fertile land and petroleum, producing a large amount of Mexico's coffee and electricity. The wealth generated in Chiapas did not reach the indigenous people there. ${ }^{12}$

Over the eleven years following the first declaration, five more declarations were issued. The Second Declaration of the Lacandon Jungle, released just a few months after the first, reestablished the reasons for the group's purpose and to assert its success in maintaining "international conventions of war." Calling for government changes and for the people of Mexico to stand with the EZLN against the "bad government" and for democracy, the EZLN continued to show its determination in the face of strong military and political opposition. ${ }^{13}$ Subsequent declarations continued to call for, and expand upon, the demands set forth prior while decrying the Mexican government's failure to follow through with its promises.

In February, 1996 the EZLN and the Mexican government gathered, with indigenous peoples, in order to reach an understanding. The San Andrés Accords were meant to form a "new relationship between indigenous peoples and the State.”The Accords called for new policies to allow for greater indigenous participation in decision-making and the raising of standards of living for the indigenous peoples of Mexico. ${ }^{14}$ Unfortunately, however, the process of getting the Accords put into effect legally was slow and fraught with problems. For example, President Ernesto Zedillo refused to accept the proposal as it

12 Edward J. Williams and Donald E. Schulz, eds., Mexico Faces the 21st Century (Westport: Greenwood Press, 1995), 166.

13 CCRI-CG, “Second Declaration of the Lacandon Jungle,"Wikisource, June 1994, accessed May 13, 2015, http://en.wikisource.org/wiki/Second_Declaration_of_the_Lacandon_Jungle.

14 "Joint Declaration that the Federal Government and the EZLN shall submit to National Debating and Decision-Making Bodies," 16 February 1996, accessed May 16, 2015, United Nations, http://peacemaker.un.org/document-search?field_pacountry_tid=mexico 
was; he wanted to make "minor" adjustments prior to approval. Any adjustments, however, would void the meaning of the proposal in the eyes of the EZLN and they withdrew from further talks in January of $1997 .{ }^{15}$

\section{“The War of Ink and Internet:" Subversion Through the Media}

The emergence of the Internet in the early 1990s coincided perfectly with the rise of the EZLN. The Zapatistas utilized the fledgling technology to take their local news to the international stage and their survival was more than likely tied to this ability to communicate with a global audience. ${ }^{16}$ When combined with the "heavy-handed response" of the Mexican government, the EZLN's successful use of the media and Internet allowed for various groups from around the world to rally around the movement. ${ }^{17}$ Beyond using the net and media attention to subvert the government, the EZLN has been influential in subverting the means of traditional guerrilla warfare. As Graham Fuller and his coauthors explain, the Zapatistas have demonstrated that the "old models of struggle," of violently upending governments, is not necessarily the best way to create change in the "information age." ${ }^{18}$

The EZLN's use of the Internet and other media outlets has earned the conflict the title of "la guerra de tinta e Internet [the war of ink and internet]," as José Ángel Gurría described it in $1995 .{ }^{19}$ The Mexican government had tried to isolate the EZLN and limit their coverage, but through the Internet and independent journalists the group has been successful in maintaining their "political connections" abroad. ${ }^{20}$ Their "war of words, images, imagination and

15 Gemma van der Haar, "The Zapatista Uprising and the Struggle for Indigenous Autonomy," European Review of Latin American and Caribbean Studies, no. 76 (April 2004): 101.

16 Jose Rabasa, Without History: Subaltern Studies, the Zapatista Insurgency, and the Specter of History (Pittsburg: University of Pittsburg Press, 2010), 39.

17 Graham Fuller, David Ronfeldt, and John Arquilla, The Zapatista Social Netwar in Mexico (Santa Monica: RAND Corporation, 1999), 3.

18 Graham Fuller, David Ronfeldt, and John Arquilla, The Zapatista Social Netwar in Mexico (Santa Monica: RAND Corporation, 1999), 5.

19 Luis Hernández Navarro, “Chiapas: La Otra Guerra de Tinta e Internet," La Jornada, December 1, 2009, accessed June 1, 2015 http://www.jornada.unam.mx/2009/12/01/opinion/017a2pol.

20 Harry Cleaver, "The Zapatistas and the Electronic Fabric of Struggle," University of Texas at Austin, http://la.utexas.edu/users/hcleaver/zaps.html (accessed May 31, 2015) 
organization" was integral to that success. ${ }^{21}$ Outsiders posting and reposting every bit of available information have been helpful too. Everything from EZLN communiqués to official government reports to mainstream news articles are disseminated across the net, thus subverting official channels and biases. The use of the Internet has allowed for a more informed and capable audience in assessing the situation in Chiapas. ${ }^{22}$ The ELZN's use of eloquent rhetoric and the Web provides a useful tool for other revolutionary groups. As Kathleen Bruhn asserts, other organizations better versed in "military maneuvers than in writing may feel compelled to imitate the communications strategy of the EZLN.” ${ }^{23}$

While the Internet has been key for the EZLN, it should be noted that Chiapas is an impoverished region with virtually no internet access. The communiqués were generally written by hand and then passed on to someone with access to the Internet. ${ }^{24}$ However, this does not diminish the impact that the Internet has had on the movement in regards to spreading the word and providing outside support, which were vital to the movement's survival. Tim Golden, writer for the New York Times, asserts that "were it not for the Zapatistas' vocal partisans in the developed world that Mexico's leaders are so determined to join, the authorities might have crushed them long ago." ${ }^{25}$ Due to the EZLN's ability to gain some popular support, particularly from abroad, the Mexican government would have faced a public relations nightmare had they crushed the group.

As previously mentioned, outside support has been crucial to the movement as well. Innumerable scholars, journalists, and even celebrities have been fascinated (and even endorsed) the EZLN, especially in the early years. For exam-

21 Ibid.

22 Ibid.

23 Kathleen Bruhn, "Antonio Gramsci and the Palabra Verdadera: The Political Discourse of Mexico's Guerrilla Forces,” Journal of Interamerican Studies and World Affairs 41, no. 2 (Summer 1999): 51.

24 Juana Ponce de León, "Editor's Note: Traveling Back for Tomorrow," in Our Word is Our Weapon: Selected Writings, ed. Juana Ponce de León (New York: Seven Stories Press, 2002), xxiii.

25 Tim Golden, "Revolution Rocks: Thoughts of Mexico's First Postmodern Guerilla Commander," New York Times, April 8, 2001, (accessed May 16, 2015), https://www.nytimes.com/books/01/04/08/reviews/010408.08goldent.html. 
ple, Zack de la Rocha, vocalist of the popular American rap-metal band Rage Against the Machine, was an avid supporter of the Zapatistas, journeying to Chiapas in demonstrations of solidarity. He explained that in his numerous trips to the region, he has witnessed the isolation forced upon Chiapas as well as the government's failure to act accordingly, opting instead to send in troops. The musician recalled that when he organized a group of students, artists, and activists to go to Chiapas prior to the San Andrés Accords and there they saw the military buildup and intimidation of community members by government forces. Many of the band's songs reflect the Zapatista struggle and de la Rocha's experiences with the group. ${ }^{26}$ Essential to the group's online presence and Internet appeal was Subcomandante Marcos.

\section{A Face for the Faceless: Subversion and the Subcomandante}

Subcomandante Marcos was a key figure in some of the relative success the EZLN had in gathering support against the government. Edward Williams and Donald Schulz explain that the "charismatic ski-masked commando" became the EZLN's spokesman, and a folk hero. ${ }^{27}$ Marcos' "skillfully deployed combination of self-effacing subordination to the community he serves and individual charisma" was the source of intrigue and admiration that surrounds him. ${ }^{28}$ Marcos was a major component of the EZLN's propaganda machine and was responsible for many of the group's communiqués. ${ }^{29}$

On February 9, 1995, the Mexican government revealed "Marcos" identity. In order to discredit the rebel's "mythic hero" status and subvert the EZLN's efforts, the government identified him as Rafael Sebastián Guillén Vicente, a former middle-class university professor from Mexico City-this was rather unsuccessful, however. Marcos was able to win back sympathy by "portraying himself as a victim" of the oppressive governmental forces. ${ }^{30}$ In her examina-

\footnotetext{
26 "Interview with Zach, from Chiapas, Mexico."

27 Williams and Schulz, Mexico Faces the 21st Century, 12-3.

28 Beth Ellen Jorgensen, "Making History: Subcomandante Marcos in the Mexican Chronicle," South Central Review 21, no. 3 (Fall 2004): 85.
}

29 Golden, "Revolution Rocks."

30 Jorgensen, "Making History," 98-9. 
tion of Juan Villoro's work, Beth Jorgensen noted that masks and legends are a crucial part of Mexican history, and often endure longer than the "realities that inspired them." 31 The man had been overshadowed by his mask.

"Marcos," however, was not the only nom de guerre utilized by the charismatic commando. With the launching of the Other Campaign in 2006, Marcos took on the role of Delegate Zero and toured Mexico. ${ }^{32}$ John Ross described the campaign as an "anti-electoral crusade designed to weld the underclass struggle groups into a new left alliance," with Zero propelling himself into the spotlight once again during the electoral process; however, Ross argued that, due to the attention Zero had garnered, he was propelled into "the very class that the Other Campaign detests." ${ }^{33}$

Another nom de guerre was the result of a paramilitary assault on the autonomous community La Realidad on May 2, 2014-where a school and clinic were attacked - that left fifteen Zapatistas injured and one killed. The one killed was Jose Luis Solis Lopez, whose pseudonym was Galeano. ${ }^{34}$ Subcomandante Marcos, and the EZLN leadership, concluded that the attack was premeditated and "cultivated from above," implicating the National Action Party (PAN), the Revolutionary Institutional Party (PRI), the Green Ecological Party (PRI branch that operated in Chiapas), and the paramilitary group CIOAC-Historica. ${ }^{35}$ The paramilitary group ambushed the victims and brutally murdered Lopez. ${ }^{36}$ On May 25, 2014 at approximately 2:00 am, Subcomandante Marcos "ceased to exist" so that Galeano may live on. ${ }^{37}$ Marcos wrote, "to satisfy the impertinence that is death, in place of Galeano we

31 Ibid.

32 Ramor Ryan, “Zapatistas Launch 'Other' Campaign,” The Independent, January 12, 2006, accessed May

20, 2015, https://indypendent.org/2006/01/12/zapatistas-launch-other-campaign.

33 John Ross, “The Delegate Zero Factor,” The San Francisco Bay Guardian, May 17, 2006, accessed May

20, 2015, http://www.sfbg.com/2006/05/17/delegate-zero-factor.

34 Leonidas Oikonomakis, "Farewell Marcos, Long Live Subcomandante Galeano," Roarmag, May 26,

2014, accessed May 20, 2015, http://roarmag.org/2014/05/subcomandante-marcos-steps-down-galeano/.

35 Subcomandante Insurgente Marcos, "Pain and Rage," Enlace Zapatista, May 8, 2014, accessed May 20,

2015, http://enlacezapatista.ezln.org.mx/2014/05/10/pain-and-rage/.

36 Ibid.

37 Subcomandante Insurgente Marcos, "Between Light and Shadow,” Enlace Zapatista, May 24, 2014, accessed May 20, 2015, http://enlacezapatista.ezln.org.mx/2014/05/27/between-light-and-shadow/. 
put another name, so that Galeano lives and death takes not a life but just a name-a few letters empty of any meaning, without their own history or life." 38

Marcos and the EZLN command asserted the expendability of the persona of Marcos. By this point in time, another subcomandante had filled Marcos' role as spokesman for the group. Subcomandante Insurgente Moisés, like Marcos, joined the EZLN in the mid-1980s and had a prominent role. Unlike Marcos, however, Moisés was an indigenous Tzetal; Marcos was a mestizo. ${ }^{39}$ Initially, Marcos was never meant to be a spokesperson; the EZLN did not intend to have a mestizo as their "face," instead they had slated an indigenous Zapatista for the role, but he was killed. . Marcos then stepped up and took advantage of his "allure" to catapult the group into the spotlight, which did have its benefits; however, this also had the negative impact of intertwining Marcos and the movement to the point of them being inseparable. ${ }^{40}$

Marcos had served his purpose of drawing attention to the plight of the indigenous by being a faceless entity in which anyone could project themselves in order to sympathize with the movement. “One day Marcos' eyes were blue, ... green, ... or black - all depending on who did the interview..." ${ }^{41}$ Marcos could represent everybody and nobody at once, and that was his power; however, Marcos, as he explained, became a distraction, and that was one reason why that persona was eliminated and that of Galeano was taken in its place. While Marcos was a key in the EZLN's subversion of the Mexican government, his prominent role and inadvertent fame partially subverted the group's goals.

\section{Twenty Years On: Success or Failure?}

The Zapatistas have made little progress outside of Chiapas in the last twenty-one years and various scholars and media outlets have pointed out the

38 Ibid.

39 Gloria Muñoz Ramirez, "EZLN Introduces New Subcomandante," Upside Down World, February 16, 2013, accessed May 20, 2015, http://upsidedownworld.org/main/mexico-archives-79/4132-ezln-introduces-new-subcomandante-.

40 Oikonomakis, "Farewell Marcos, Long Live Subcomandante Galeano."

41 Marcos, "Between Light and Shadow." 
increasing irreverence of Marcos and the EZLN; however, does that mean that the group has failed in its lofty goals? Bethaney Turner argued that the international support generated through the Internet does not guarantee significant changes in society, and the first decade of the EZLN's efforts had not "precipitated the radical reconstruction of the Mexican political system that they had hoped for." ${ }^{22}$ Turner perceived the movement as having deflated over time, and was not alone in that assessment. Turner perceived the movement as having deflated over time, and was not alone in that assessment. Mihalis Mentinis argued that even though the EZLN have attracted a large amount of attention, there was little consensus on their efficacy.

Furthermore, according to Mentinis, the Zapatistas "have failed to bring about radical change, and have $\mathrm{m}^{43}$ ade little progress on their broader political agenda." Even in the first few years of the Zapatista movement, some have argued that the EZLN's "capacity for insurgency" and its "social netwar" were "past its peak." ${ }^{44}$ Not everybody was content with this analysis. As Immanuel Wallerstein explained, it was much like the answer that Zhou Englai was rumored to have provided as a response to the French Revolution: "It is too early to tell." ${ }^{25}$

Whether or not greater successes throughout Mexico will arise as a direct result of the Zapatistas is unknown, but the movement has been successful on a local level. As Marcos explained, "[ $t$ ]he mere indisputable fact that the EZLN had not only not been weakened, much less disappeared, but rather had grown quantitatively and qualitatively would have been enough for any moderately intelligent mind to understand that, in these 20 years, something had changed within the EZLN and the communities." ${ }^{\prime 6}$ The EZLN is still

42 Bethaney Turner, "Information-Age Guerrillas: The Communication Strategies of the Zapatistas," $M / C$ Journal 8, no. 2 (June 2005), accessed June 7, 2015,

http://journal.media-culture.org.au/0506/01-turner.php.

43 Mihalis Mentinis, Zapatistas: The Chiapas Revolt and What It Means for Radical Politics (London: Pluto Press, 2006), xii.

44 Fuller, Ronfeldt, and Arquilla, The Zapatista Social Netwar in Mexico, 4.

45 Immanuel Wallerstein, "What Have the Zapatistas Accomplished?" Immanuel Wallerstein, January 1, 2008, accessed June 7, 2015, http://iwallerstein.com/what-have-the-zapatistas-accomplished/.

46 Marcos, "Between Light and Shadow." 
going twenty years later, which demonstrates some level of success. One of the greatest successes of the Zapatistas has come in the form of local, self-governing communities in Chiapas.

\section{Bypassing the Government: Autonomous Communities}

After withdrawing from negotiations with the government in 2007 and with legal avenues effectively at an impasse, the EZLN moved forward with the creation of a system of self-governance, forming autonomous municipalities, regardless of Federal approval, thus subverting governmental dominion over the region. Gemma van der Haar explained that these autonomous municipalities serve not only as a form of more legitimized resistance, but as governmental structures to provide a system of justice, education, health care, economic development, and more in a flexible manner based on local conditions. These autonomous communities are made up of locally elected councils and each of the systems (e.g. education, healthcare) are managed by commissions made up of local peoples. ${ }^{47}$ The EZLN helped establish autonomous indigenous communities when the government failed to follow through with promises it made.

These autonomous communities were able to form with some outside help. In a brief history of these autonomous zones, Subcomandante Marcos noted repeatedly that it was with the support of national and international civil societies that these communities could form. Marcos also explained, however, that the arrangement was not perfect and has its ups and downs; its own contradictions. Despite the problems, the autonomous communities-and the support of civil societies-helped improve the conditions, even if only a little, of normally excluded peoples (e.g. the indigenous, young persons, women, and a whole host of "others"). ${ }^{48}$ Where the government failed in creating a better situation for the indigenous people, the EZLN helped form autono-

47 van der Haar, 102-3.

48 Subcomandante Insurgente Marcos, “Chiapas: La Treceava Estela, Quinta Parte: Una Historia," Enlace Zapatista, July 2003, accessed May 16, 2015, http://enlacezapatista.ezln.org.mx/2003/07/21/chiapas-la-treceava-estela-quinta-parte-una-historia/. 
mous communities. This not only garnered some support of the local peoples in Chiapas, but also more support nationally and internationally.

\section{Conclusion}

The Zapatista Army of National Liberation's prolific use of the Internet and media as well as the allure of the enigmatic Subcomandante Marcos were key to their longevity and subversion. The establishment of autonomous communities were also immensely important and were arguably their greatest achievement. Internet usage and appeal had earned the early rebellion the title "The War of Ink and Internet," while many have claimed Marcos and the EZLN to represent the first "post-modern revolution." Despite not having accomplished a nation-wide revolution in Mexico, the Zapatistas have had some success at the local level for the indigenous people in Chiapas, which was a key motivation for the movement. 
Bruhn, Kathleen. "Antonio Gramsci and the Palabra Verdadera: The Political Discourse of Mexico's Guerilla Forces." Journal of Interamerican Studies and World Affairs 41, no. 2 (Summer 1999): 29-55.

Carrigan, Ana. "Chiapas: The First Post-Modern Revolution." The Fletcher Forum 19, no. 1 (1995): 72-98.

CCRI-CG. "Second Declaration of the Lacandon Jungle." Wikisource. June 1994. Accessed May 13, 2015. http://en.wikisource.org/wiki/Second_Declaration_of_ the_Lacandon_Jungle.

Cleaver, Harry. "The Zapatistas and the Electronic Fabric of Struggle." University of Texas at Austin. Accessed May 31, 2015. http://la.utexas.edu/users/hcleaver/zaps. html.

Froehling, Oliver. "The Cyberspace 'War of Ink and Internet' in Chiapas, Mexico." Geographical Review 87, no. 2 (April 1997): 291-307.

Fuller, Graham, David Ronfeldt, and John Arquilla. The Zapatista Social Netwar in Mexico. Santa Monica: RAND Corporation, 1999.

General Command of the EZLN. "First Declaration of the Lacandon Jungle: EZLN's Declaration of War." The Struggle Site. June 1993. Accessed April 20, 2015. http://struggle.ws/mexico/ezln/ezlnwa.html.

Golden, Tim. "Revolution Rocks: Thoughts of Mexico's First Postmodern Guerilla Commander." New York Times. April 8, 2001. Accessed May 16, 2015. https://www. nytimes.com/books/01/04/08/reviews/010408.08goldent.html.

Jorgensen, Beth Ellen. "Making History: Subcomandante Marcos in the Mexican Chronicle." South Central Review 21, no. 3 (Fall 2004): 85-106.

Jung, Courtney. "The Politics of Indigenous Identity: Neoliberalism, Cultural Rights, and the Mexican Zapatistas." Social Research 70, no. 2 (Summer 2003): 439-40.

Marcos. "Between Light and Shadow." Enlace Zapatista. May 24, 2014. Accessed May 20, 2015. http://enlacezapatista.ezln.org.mx/2014/05/27/between-light-and-shadow/. 
. "Chiapas: La Treceava Estela, Quinta Parte: Una Historia." Enlace Zapatista. July 2003. Accessed May 16, 2015. http://enlacezapatista.ezln.org.mx/2003/07/21/ chiapas-la-treceava-estela-quinta-parte-una-historia/.

. "Pain and Rage." Enlace Zapatista. May 8, 2014. Accessed May 20, 2015. http://enlacezapatista.ezln.org.mx/2014/05/10/pain-and-rage/.

Mentinis, Mihalis. Zapatistas: The Chiapas Revolt and What It Means for Radical Politics. London: Pluto Press, 2006.

Music Fan Clubs. "Interview with Zach, from Chiapas, Mexico." Music Fan Clubs. July 7, 1998. Accessed April 18, 2015. http://www.musicfanclubs.org/rage/articles/ chiapas.html.

Navarro, Luis Hernández. "Chiapas: La Otra Guerra de Tinta e Internet.” La Jornada. December 1, 2009. Accessed June 1, 2015. http://www.jornada.unam. mx/2009/12/01/opinion/017a2pol.

Oikonomakis, Leonidas. "Farewell Marcos, Long Live Subcomandante Galeano." Roarmag. May 26, 2014. Accessed May 20, 2015. http://roarmag.org/2014/05/ subcomandante-marcos-steps-down-galeano/.

Ponce de León, Juana. "Editor's Note: Traveling Back for Tomorrow," in Our Word is Our Weapon: Selected Writings. Edited by Juana Ponce de León. New York: Seven Stories Press, 2002.

Rabasa, Jose. Without History: Subaltern Studies, the Zapatista Insurgency, and the Specter of History. Pittsburg: University of Pittsburg Press, 2010.

Radu, Michael. "Mexico: Slouching Toward Normality." The Washington Quarterly 23, no. 3 (Summer 2000): 41-56.

Ramirez, Gloria Muñoz. "EZLN Introduces New Subcomandante.” Upside Down World. February 16, 2013. Accessed May 20, 2015. http://upsidedownworld.org/ main/mexico-archives-79/4132-ezln-introduces-new-subcomandante.

Ross, John. “The Delegate Zero Factor.” The San Francisco Bay Guardian. May 17, 2006. Accessed May 20, 2015. http://www.sfbg.com/2006/05/17/delegate-zerofactor. 
Ryan, Ramor. "Zapatistas Launch 'Other' Campaign.” The Indypendent. January 12, 2006. Accessed May 20, 2015. https://indypendent.org/2006/01/12/zapatistaslaunch-other-campaign.

Schools for Chiapas. "Early and Extensive Interview with Subcomandante Marcos." Schools for Chiapas. May 1994. Accessed April 20, 2015. http://schoolsforchiapas. org/wp-content/uploads/2014/03/Interview-with-Subcomandante-Marcos.pdf.

Turner, Bethaney. "Information-Age Guerrillas: The Communication Strategies of the Zapatistas.” M/C Journal 8, no. 2 (June 2005). Accessed June 7, 2015. http://journal. media-culture.org.au/0506/01-turner.php.

United Nations. "Joint Declaration that the Federal Government and the EZLN shall submit to National Debating and Decision-Making Bodies." United Nations. February 16, 1996. Accessed May 16, 2015. http://peacemaker.un.org/documentsearch?field_pacountry_tid=mexico.

van der Haar, Gemma. "The Zapatista Uprising and the Struggle for Indigenous Autonomy." European Review of Latin American and Caribbean Studies, no. 76 (April 2004): 99-108.

Wallerstein, Immanuel. "What Have the Zapatistas Accomplished?" Immanuel Wallerstein. January 1, 2008. Accessed June 7, 2015. http://iwallerstein.com/whathave-the-zapatistas-accomplished/.

Williams, Edward J., and Donald E. Schulz, eds. Mexico Faces the 21st Century. Westport: Greenwood Press, 1995. 